\title{
Evaluation of Some Metals Content and Physicochemical Properties of Some Major Rivers as Sources of Irrigation Water in Mid-Benue Trough
}

\author{
*ABAGYEH, SOI; AGBER, PI; ZUBAIRU, A \\ Department of Soil Science, College of Agronomy, University of Agriculture, Makurdi, Benue State, Nigeria \\ *Email: abacks1959@gmail.com
}

\begin{abstract}
Irrigation Water were sampled from some major rivers in the mid-section of Benue Trough for two consecutive years, 2011 and 2012 and analysed for some metals contents and physicochemical properties. The results showed that irrigation water were slightly $(\mathrm{pH}$ 6.5) to moderately $(\mathrm{pH} 5.5)$ acidic and good for irrigation with minimal or no liming. Very low $\mathrm{pH}$ delays nutrients uptake by plants and therefore plant metabolism. Levels of total soluble salts, $\mathrm{Mg}^{2+}, \mathrm{Ca}^{2+}, \mathrm{Na}^{+}$and $\mathrm{K}^{-}$were within the acceptable limits for irrigation water. Salinity of water was low and ranged from 0.00 to $0.05 \mathrm{dsm}^{-1}$ with EC from 64.30 to $104.50 \mu$ mhos which falls below the upper limit of standard for irrigation water $\left(2,000 \mu\right.$ mhos). Total suspended solids concentrations were from 9.00 to $13.00 \mathrm{mgl}^{-1}$. These ranges are relatively low to medium compared to the standard limits and may pose no harm or threat to plants irrigated or cause damage to pumps if screens are not used to exclude them. The anions: $\mathrm{NO}_{3}{ }^{-}, \mathrm{HCO}_{3}{ }^{-}, \mathrm{CO}_{3}{ }^{2-}, \mathrm{Cl}^{-}$ $\mathrm{SO}_{4}{ }^{2-}$ levels were however less than the upper limit for irrigation water. Therefore, the waters were highly suitable for irrigation without improvement. Trace elements were 0.44 to $0.93 \mathrm{mgl}^{-1}$ for $\mathrm{Fe}, 0.03$ to $0.12 \mathrm{mgl}^{-1}$ for $\mathrm{Mn}, 10.00$ to $14.00 \mathrm{mgl}^{-1}$ for $\mathrm{Cd}, 3.00$ to $5.00 \mathrm{mgl}^{-1}$ for $\mathrm{Pb}$ and 0.25 to $0.45 \mathrm{mgl}^{-1}$ for $\mathrm{B}$ (maximum application rates should not exceed that which allows normal crop growth as plant uptake is so small). In general terms therefore, qualities of irrigation water in the study sites conformed to the specifications for irrigation water.
\end{abstract}

DOI: https://dx.doi.org/10.4314/jasem.v22i3.24

Copyright: Copyright (C) 2018 Abagyeh et al. This is an open access article distributed under the Creative Commons Attribution License (CCL), which permits unrestricted use, distribution, and reproduction in any medium, provided the original work is properly cited

Dates: Received: 07 December 2017; Revised: 20 February: 2018; Accepted: 13 March 2018

Key words: Suitability, evaluation, Sources of Irrigation Water, Major Rivers, Mid-Benue Trough

Farmers of the sub-humid region of southern guinea savanna practice mainly subsistence agriculture employing local tools such as hoes, cutlasses and pegs to clear the grasses, make either the mound or ridges and to plant such crops as yam, cassava, cocoyam, millet, maize, sorghum, groundnut, sesame, rice, sugarcane and vegetables during the rainy whereas some of these crops could be cultivated two to three times with irrigated farming in a year. Pockets of spots however, witness dry season irrigated crop production by very few peasant farmers for the production of such crops like maize and mainly vegetables on selected banks of the major rivers. Rarely does one sees mechanized farming in the rainy or dry season. The rainy seasons have sporadic rains with dry spade that a time last for weeks necessitating supplementary irrigation.

The river banks of Benue Trough are blessed with floodplains and river basins that hold great potentials for irrigation agriculture even on the largest scale. Most of their soils have been rated highly suitable for localized as well as drip irrigation (Abagyeh, 2015). Jamala et al. (2011) reported elsewhere in the upper trough of the Benue that Mubi floodplains hold great potentials for irrigation. However, the quality of irrigation water including underground water may be more significant to land suitability than soil quality as both the quality and quantity of water are critical to the successful plant production. The Rivers of Benue and Katsina Ala with their distributaries, MU and Dura respectively have sufficient water for supplementary irrigation during dry spades and total irrigation in the dry season. Unfortunately, only scanty irrigation activities by peasant farmers are conducted on the banks of these rivers during the lengthy dry season. Though, considered a critical parameter, water issues are frequently overlooked by most growers. Chemical as well as physical and biological properties may change significantly during a year particularly as demand increases on a ground well and water table is lowered (James, 2010). The aim of this research was therefore to evaluate the metal contents and physicochemical parameters in some major rivers of Mid-Benue Trough and to ascertain their suitability for irrigation.

\section{MATERIALS AND METHODS}

The Study Area: The experiment was sited within Lower Benue Basin; Latitude $7^{\circ} 23^{\prime}$ and $07^{\circ} 44^{\prime} \mathrm{N}$ and Longitude $008^{\circ} 9^{\prime} \mathrm{E}$ and $009^{\circ} 12^{\prime} \mathrm{E}$ and covered an 
estimated area of $3250 \mathrm{~km}^{2}$ in Mid-Section of Benue Trough, Southern Guinea Savanna region of Nigerian. The region experiences seven months of rainfall from April to March with periodical/intermittent dry spade and five months of dry season with attendant harmattan. The sub-humid region has mean annual rainfall between 1220 to $1500 \mathrm{~mm}$, mean monthly minimum temperatures of 20 to $21^{\circ} \mathrm{C}$ and maximum temperatures from 30 to $33^{\circ} \mathrm{C}$ with relative humidity at $72 \%$ during the day and 49 to $52 \%$ at night and solar radiation of $13 \mathrm{mjcm}^{-2} \mathrm{~d}^{-1}$ (Table 1$)$.

The trough has well developed drainage system with major rivers like Benue, Katsina Ala and their tributaries cutting across the breadth of the trough which run all year round (Figure 1).

Table 1: Climatic Data of the Mid-Benue Truogh for 2011 and 2012.

\begin{tabular}{|c|c|c|c|c|c|c|c|c|c|c|c|c|c|c|c|}
\hline \multirow{5}{*}{ 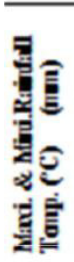 } & \multicolumn{2}{|c|}{ YEAR } & \multicolumn{2}{|c|}{ JAN FEB } & \multicolumn{3}{|c|}{ MAR APR. MAY } & \multicolumn{2}{|c|}{$\pi N . \quad \pi L$} & AUG & \multicolumn{2}{|c|}{ SEPT OCT } & \multicolumn{3}{|c|}{ NOW DEC T/M } \\
\hline & $\begin{array}{l}2011 \\
2012\end{array}$ & & & $\begin{array}{l}68.8 \\
0.5\end{array}$ & $\begin{array}{l}\infty \\
\infty\end{array}$ & $\begin{array}{l}78.0 \\
143.2\end{array}$ & & & $\begin{array}{l}87.0 \\
351.9\end{array}$ & & & 293.4 & & $\begin{array}{l}\infty \\
\infty\end{array}$ & \\
\hline & 2011 & $\operatorname{sen} x$ & 16.5 & 24.4 & 262 & 25 & 24 & 22.6 & 22 & 22.4 & 21.9 & 21.6 & 19.4 & 14.5 & \\
\hline & 2012 & $\operatorname{sen} x$ & 18.3 & 22.7 & 23.5 & 2.8 & 21.4 & 21.1 & 22 & 22.4 & 219 & 21.6 & 19.4 & 14.5 & \\
\hline & & $\max$ & 35.0 & 382 & 352 & 31.9 & 30.6 & 29.8 & 29.4 & 30.2 & 31.1 & 33.4 & 33.6 & 34.5 & \\
\hline & 2011 & $D \Delta Y$ & 38 & 72 & 72 & 68 & 77 & 82 & 84 & 86 & 84 & 84 & 70 & 44 & \\
\hline & 2012 & $\begin{array}{l}\text { XXENT } \\
\text { DAY }\end{array}$ & $\begin{array}{l}19 \\
47\end{array}$ & $\begin{array}{l}45 \\
56\end{array}$ & $\begin{array}{l}50 \\
58\end{array}$ & $\begin{array}{l}40 \\
71\end{array}$ & $\begin{array}{l}62 \\
80\end{array}$ & $\begin{array}{l}70 \\
\infty 0\end{array}$ & $\begin{array}{l}69 \\
85\end{array}$ & $\begin{array}{l}73 \\
85\end{array}$ & $\begin{array}{l}71 \\
84\end{array}$ & $\begin{array}{l}69 \\
83\end{array}$ & $\begin{array}{l}40 \\
75\end{array}$ & $\begin{array}{l}21 \\
53\end{array}$ & \\
\hline & 2011 & xлакт & $\begin{array}{l}26 \\
14.7\end{array}$ & $\begin{array}{l}38 \\
142\end{array}$ & $\begin{array}{l}28 \\
15.6\end{array}$ & $\begin{array}{l}53 \\
14.0\end{array}$ & $\begin{array}{l}64 \\
13.0\end{array}$ & $\begin{array}{l}70 \\
11.4\end{array}$ & $\begin{array}{l}73 \\
11.1\end{array}$ & $\begin{array}{l}74 \\
09.1\end{array}$ & $\begin{array}{l}73 \\
11.4\end{array}$ & $\begin{array}{l}68 \\
12.3\end{array}$ & $\begin{array}{l}55 \\
15.5\end{array}$ & $\begin{array}{l}30 \\
14.9\end{array}$ & \\
\hline & 2012 & & 12.9 & 13.2 & 15.1 & 14.4 & 139 & 12.5 & 10.5 & 10.2 & 12.1 & 13.3 & 14.5 & 15.3 & \\
\hline
\end{tabular}

Source: Nigerian Metrological Agency, Tactical Air Command Headquarters, Makurdi

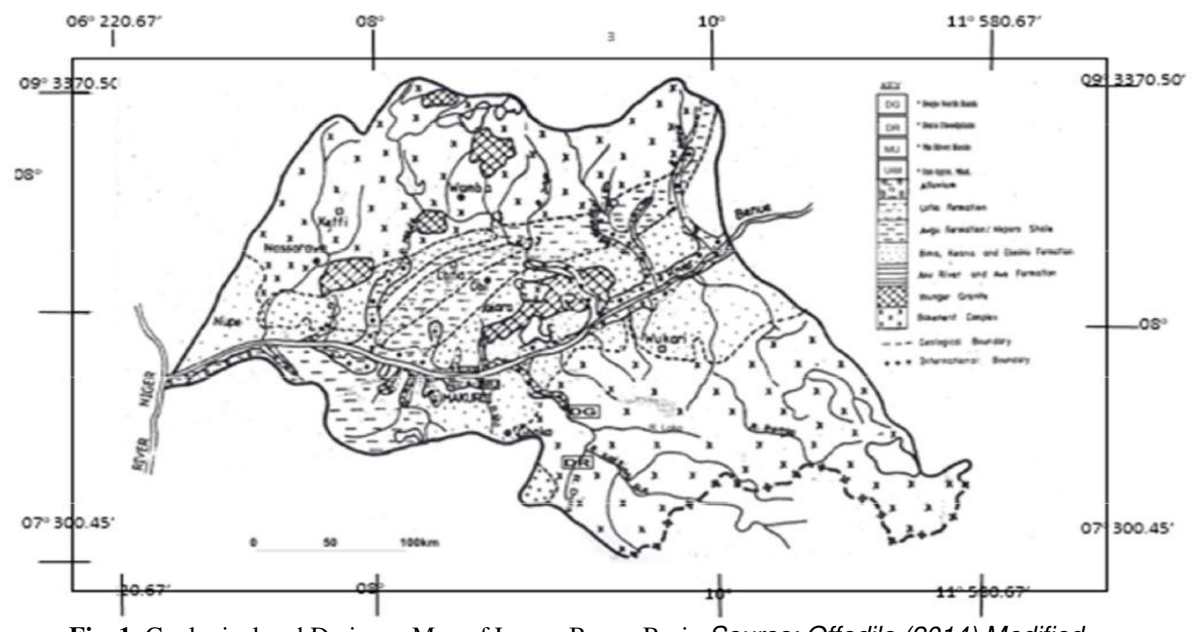

Fig. 1: Geological and Drainage Map of Lower Benue Basin Source: Offodile (2014) Modified

Water Sampling and Analysis: In each of the chosen sites, clean, one litre plastic water bottle was immersed inside the irrigation water supply source till the bottle was filled. The bottles were then properly labeled and immediately sent to the laboratory for analysis for two consecutive years, 2011 and 2012. The means of the two year data were used for the purpose of water assessment.

The temperature of irrigation water was obtained from mercury thermometer. Water $\mathrm{pH}$ was measured using a $\mathrm{pH}$ meter. Electrical conductivity of water was measured by the use of electrical conductivity metre. Atomic Absorption Spectrophotometer was used in measuring $\mathrm{Mg}^{2+}$, $\mathrm{Fe}^{2+}, \mathrm{Ca}^{2+}$ and $\mathrm{Mn}^{2+}$ while the concentrations of $\mathrm{Na}^{+}$and $\mathrm{K}^{-}$were determined by using flame photometer (IITA, 1979). The anions: $\mathrm{NO}_{3}{ }^{-}, \mathrm{HCO}_{3}{ }^{-}$, $\mathrm{CO}_{3}{ }^{2-}, \mathrm{Cl}^{-}$and $\mathrm{SO}_{4}{ }^{2-}$ were determined by titrimetric method (Landon, 1971), Sodium Adsorption Ratio (SAR) was determined using Brady (1999).

Stereospecific meters were used in the determination of Total dissolved solute (TDS) and total suspended solid (TSS) both in milligram per litre $\left(\mathrm{mgl}^{-1}\right)$. The turbidity 
of water and water colour were photo-metrically determined by employing DR-20 spectrophotometer.

All the trace elements were spectro-photometrically determined with DR-20 spectro-photometer. Lead $(\mathrm{Pb})$ and Cadmium (Cd) were extracted by dethizone method in microgram per litre $\left(\mu \mathrm{gl}^{-1}\right)$. Iron $(\mathrm{Fe})$ was determined by the method of 1,10 phenanthroline in milligram per litre $\left(\mathrm{mgl}^{-1}\right)$. Azomethine $\mathrm{H}$-method was used for determination of Boron (B) in milligram per litre $\left(\mathrm{mgl}^{-}\right.$ ${ }^{1}$ ) while the content of aluminum (Al) in the waters in milligram per litre $\left(\mathrm{mgl}^{-1}\right)$ was determined by Aluminum method.

\section{RESULT AND DISCUSSION}

The metals content, the physical as well as the chemical parameters of water of these major rivers were evaluated using the criteria in Tables 2, 3 and 4.

Water Suitability Evaluation: Water properties may change significantly during a year particularly as demand increases on a groundwell and watertable is lowered (James, 2010); so irrigation suitability water parameters were examined with means of results presented in Table 5. The results showed that irrigation water were slightly $(\mathrm{pH} 6.5)$ to moderately $(\mathrm{pH} 5.5)$ acid and good for irrigation with minimal or no liming. This may be due to water interactions with the surrounding basement rocks, rain water as well as improperly disposed or use of acidic items. Water $\mathrm{pH}$ limit for irrigation water ranged from moderately acid (5.2) to slightly acid (6.8) according to James, (2010). Very low $\mathrm{pH}$ delays nutrients uptake by plants and therefore plant metabolism. The $\mathrm{pH}$ range of these waters may only affect very few extremely acid sensitive crops which may need to be limed while strong acid loving plants may require further injection of acid in the water to appropriate $\mathrm{pH}$.

Without salts especially calcium, the soil disperses and the dispersed finer particles fill many of the smaller pores, sealing the surface and greatly reducing the rate at which water infiltrates the soil. Soil crusting and crop emergence problems often result. This is in addition to a reduction in the soil water infiltration which may ultimately cause water stress between irrigations. Application of appropriate fertilizer will correct the imbalance.

Table 2: Water Quality Criteria for Irrigation

\begin{tabular}{lll}
\hline Parameter & Good $(\mathrm{ppm})$ & $\begin{array}{l}\text { Poor } \\
(\mathrm{ppm})\end{array}$ \\
\hline Bicarbonate & 200 & 800 \\
Chloride & 100 & 300 \\
Nitrate & 300 & 500 \\
Sulphate & 200 & 500 \\
Boron & 0.3 & 0.5 \\
Total & 500 & 3000 \\
Dissolved & & \\
Salts & \\
\hline Source: FAO (1994)
\end{tabular}

Table 3: Recommended limits for constituents in reclaimed water for irrigation

\begin{tabular}{lccl}
\hline Constituents & $\begin{array}{l}\text { Long-term } \\
\text { use }\left(\mathrm{mgl}^{-1}\right)\end{array}$ & $\begin{array}{c}\text { Short-term } \\
\text { use }\left(\mathrm{mgl}^{-1}\right)\end{array}$ & $\begin{array}{l}\text { Max. conc. } \\
\left(\mathrm{mgl}^{-1}\right)\end{array}$ \\
\hline Aluminum & 5.0 & 20.0 & 3.00 \\
Boron & 0.75 & 2.0 & - \\
BiCarbonate & 5.0 & 10 & - \\
Cadmium & 0.01 & 0.05 & 0.01 \\
Copper & 0.2 & 5.0 & 0.20 \\
Iron & 5.0 & 20.0 & 5.00 \\
Lead & 5.0 & 10.00 & 5.00 \\
Zinc & 2.0 & 10.00 & 2.00 \\
Chloride & 5.0 & 9.50 & - \\
\hline Sources: Rowe and Abdel-Magid (1999), Ayers and \\
Wescot (1987) *
\end{tabular}

Total dissolved solute concentrations of irrigation water were $32 \mathrm{mgl}^{-1}$ in RK; $30 \mathrm{mgl}^{-1}$ in RB; $52 \mathrm{mgl}^{-1}$ in RD and $45 \mathrm{mgl}^{-1}$ in RM. The most common cations of interest in water are calcium $\left(\mathrm{Ca}^{2+}\right)$, magnesium $\left(\mathrm{Mg}^{+2}\right)$ and sodium $\left(\mathrm{Na}^{+}\right)$; the most common anions are bicarbonate $\left(\mathrm{HCO}_{3}{ }^{-}\right)$, chloride $\left(\mathrm{Cl}^{-}\right)$and sulphate $\left(\mathrm{SO}_{4}{ }^{2-}\right.$ ). The concentrations of $\mathrm{Ca}^{2+}, \mathrm{Mg}^{2+}, \mathrm{Na}^{2+}$ and $\mathrm{K}^{+}$were very low in these waters and ranged from 1.23 to 1.75 $\mathrm{mgl}^{-1}$ in $\mathrm{R}, 0.41$ to $0.56 \mathrm{mgl}^{-1}, 0.26$ to $0.40 \mathrm{mgl}^{-1}$ and 0.11 to $0.50 \mathrm{mgl}$ respectively in RK, RD, RM and RB. These values fall within the acceptable limits as suggested by the FAO (1994). Agber et al., (2017) reported that the total dissolved salts in both Makurdi and Lafia waters could be classified as "fresh and good" for irrigation purposes with no permeability problems and clogging iffects.

Table 4: Permissible Limits for ECw, Total Dissolved Solids and SAR Classes for Irrigation Water

\begin{tabular}{lllll}
\hline Classes & $\mathrm{EC}_{\mathrm{w}}$ & $\mathrm{TDS}$ & \multicolumn{2}{c}{$\mathrm{SAR}$} \\
\hline Class & $(\mu \mathrm{mhos})$ & $\begin{array}{l}\text { Gravimetric } \\
(\mathrm{ppm})\end{array}$ & $/^{* *}$ & \\
\hline 1.Excellent & 250 & 175 & $1-4$ & $<10$ \\
2. Good & $250-750$ & $175-525$ & $4-8$ & $10-18$ \\
3. & $750-2,000$ & $525-1,400$ & $8-12$ & $18-26$ \\
$\begin{array}{l}\text { Permissible/Fair } \\
\text { 4. Doubtful/- }\end{array}$ & $2,000-$ & $1400-2,100$ & $12-15$ & - \\
& 3,000 & & & \\
5. & 3,000 & 2,100 & 15 & $>26$ \\
Unsuitable/Poor & & & & \\
\hline
\end{tabular}

Sources: Rowe and Abdel-Magid (1999), Ayers and Wescot $(1987) * /$ Fao $(1994)^{*}$ Key: TDS = Total Dissolved Solids

Total suspended solids concentration was $9 \mathrm{mgl}^{-1}$ in $\mathrm{RK}, 8 \mathrm{mgl}^{-1}$ in $\mathrm{RB}, 12 \mathrm{mgl}^{-1}$ in $\mathrm{RM}$ and $13 \mathrm{mgl}^{-1}$ in $\mathrm{RD}$ water. These ranges are relatively low to medium compared to the standard limits and may pose no harm or threat to plants irrigated with the water. Suspended organic as well as inorganic sediments however cause problem in irrigation systems through clogging of gates, sprinklers heads and drippers. They can cause damage to pumps if screens are not used to exclude them. 
The salinity of water was $0.05 \mathrm{dsm}^{-1}$ in RK; $0.01 \mathrm{dsm}^{-}$ 1 in RD; $0.01 \mathrm{dsm}^{-1}$ in RM and $0.00 \mathrm{dsm}^{-1}$ in RB. The low electrical conductivity and salinity of the water may be due to the low concentrations of total dissolved salt content in the water. This conformed to the findings of Obi (2000). Electrical conductivity $\left(\mathrm{EC}_{\mathrm{W}}\right)$ varied from very low to low, 64.30 to 104.5 $\mu$ mhos in these sites and fall below the upper limit $(2,000 \mu$ mhos $)$ of standard for irrigation water by Rowe and Abdel-Magid (1995). Thus, crops irrigated with these waters cannot be prone to physiological draught condition that comes from high salts concentrations.

Low salinity water especially below $0.2 \mathrm{dsm}^{-1}$ (2000 $\mu$ mhos) is corrosive and tends to leach surface soils free of soluble minerals and salts (especially calcium). This reduces their strong stabilizing influence on soil aggregates and soil structure according to James (2010). However, where salt problem occurs, drainage, leaching, and changes to more salt tolerant crops are used to avoid long-term salinity build-up but other cultural practices (more frequent irrigation, land grading, and methods of seedling and timing of fertilization) may be needed to deal with possible short-term or temporary increases in salinity which may be equally detrimental to crop yield.

Table 5: Metals Content with Physico-Chemical Properties in Some Major River Water, Mid-Section of Benue Trough

\begin{tabular}{llllll}
\hline Properties & Unit & RK & RD & RM & RB \\
\hline Temperature & ${ }^{\circ} \mathrm{C}$ & 30.0 & 30.1 & 30.20 & 30.20 \\
Water pH & $\mathrm{H}_{2} \mathrm{O}$ & 6.5 & 6.5 & 6.00 & 5.50 \\
Salinity & $\mathrm{dms}^{-1}$ & 0.05 & 0.10 & 0.1 & 0.06 \\
Total & $\mathrm{mgl}^{-1}$ & 32.0 & 52.00 & 45.0 & 30.0
\end{tabular}

Dissolved

Solute

$\begin{array}{llllll}\text { Total } & \mathrm{mgl}^{-1} & 9.0 & 13.00 & 12.0 & 8.00\end{array}$

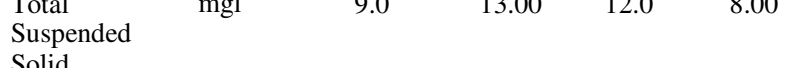

Solid

$\begin{array}{llllll}\text { Turbidity } & \text { FAU } & 4.0 & 1.00 & 1.5 .0 & 10.00\end{array}$

\begin{tabular}{llllll} 
Colour & ALPHA & 95.0 & 153.00 & 144.00 & 77.00 \\
\hline Lead & $\mathrm{mgl}^{-1}$ & 4.05 & 5.00 & 5.00 & 3.00
\end{tabular}

$\begin{array}{llllll}\text { Cadmium } & \mu \mathrm{gl}^{-1} & 12.0 & 14.00 & 13.00 & 10.00\end{array}$

$\begin{array}{llllll}\text { Boron } & \mathrm{mgl}^{-1} & 0.35 & 0.25 & 0.30 & 0.45\end{array}$

$\begin{array}{llllll}\text { Aluminium } & \mathrm{mgl}^{-1} & 0.12 & 0.09 & 0.10 & 0.11\end{array}$

\begin{tabular}{llllll} 
Iron & $\mathrm{mgl}^{-1}$ & 0.66 & 0.93 & 0.88 & 0.44 \\
\hline $\mathrm{Ca}^{-1}$
\end{tabular}

$\begin{array}{llllll}\mathrm{Ca}^{2+} & \mathrm{mgl}^{-1} & 1.30 & 1.23 & 1.75 & 1.47\end{array}$

$\begin{array}{llllll}\mathrm{Mg}_{+}{ }^{2+} & \mathrm{mgl}^{-1} & 0.56 & 0.41 & 0.49 & 0.46\end{array}$

$\begin{array}{llllll}\mathrm{Na}^{+} & \mathrm{mgl}^{-1} & 0.27 & 0.34 & 0.40 & 0.26\end{array}$

\begin{tabular}{llllll}
$\mathrm{K}^{+}$ & $\mathrm{mgl}^{-1}$ & 0.20 & 0.50 & 0.45 & 0.11 \\
\hline
\end{tabular}

\begin{tabular}{llllll}
$\mathrm{Mn}^{2+}$ & $\mathrm{mgl}^{-1}$ & 0.05 & $\mathrm{ND}$ & 0.03 & 0.12 \\
\hline $\mathrm{NO}_{3}{ }^{-1}$ & $\mathrm{mgl}^{-1}$ & 0.0020 & 0.0018 & 0.0013 & 0.00
\end{tabular}

\begin{tabular}{llllll}
$\mathrm{NO}_{3}$ & $\mathrm{mgl}$ & 0.0020 & 0.0018 & 0.0013 & 0.00 \\
$\mathrm{HCO}^{-}$ & $\mathrm{mgl}^{-1}$ & 1.50 & 2.50 & 2.75 & 1.80 \\
$\mathrm{CO}_{3}{ }^{-}$ & $\mathrm{mgl}^{-1}$ & 1.60 & 2.71 & 3.50 & 2.03 \\
$\mathrm{SO}_{4}{ }^{-{ }^{-}}$ & $\mathrm{mgl}^{-1}$ & 1.55 & 2.48 & 2.52 & 1.75 \\
$\mathrm{Cl}^{-}$ & $\mathrm{mgl}^{-1}$ & 0.85 & 1.00 & 0.90 & 1.25 \\
\hline $\mathrm{SAR}$ & - & 0.312 & 0.415 & 0.357 & 0.29 \\
$\mathrm{ESP}$ & $\%$ & 11.59 & 13.71 & 12.94 & 11.3 \\
\hline
\end{tabular}

The nitrate ion concentration requirement for surface water irrigation is $<0.3 \mathrm{mgl}^{-1}$. Nitrate stimulates plant growth; however, high nitrate level is toxic to young plants and also results in phytoplankton or macrophyte proliferations (Nagtal et al., 1997). The studied water had a range, from 0.0013 to $0.0021 \mathrm{mgl}^{-1}$, far below the $0.3 \mathrm{mgl}^{-1}$ limit, indicating that the waters were highly suitable for irrigation and therefore need no further input. Low levels of Sulphate $\left(\mathrm{SO}_{4}{ }^{2-}\right)$ were recorded with values from a 1.55 to $2.75 \mathrm{mgl}^{-1}$. The concentrations conformed to the FAO (1994) standard and may not require additional input to improve the water.

Irrigation waters had SAR values of 0.312 at $\mathrm{RK}, 0.415$ at RD, 0.357 at RM and 0.295 at RB. Higher values were recorded in water of the RD and RM than those of RB and RK that may be associated with the quantum of the water in flock. SAR value of $<4$ is the excellent class for irrigation water (Ayers and Wescot, 1987; FAO, 1994) while SAR values from 2 to 6 indicate low 
sodium concentration (Landon, 1991). Thus, indicating that waters of the study area were excellent for irrigation purposes. Not all trace elements are toxic, in small quantities, many (Fe, Mn, Mo, Zn, B) are essential for plant growth. However excessive quantities of $\mathrm{Fe}, \mathrm{Mn}, \mathrm{Mo} \mathrm{Zn}$ and $\mathrm{B}$ can cause undesirable accumulation in plant tissue and growth reductions. Most are readily fixed and cannot accumulate in soils because this process is largely irreversible. In almost all cases where elements are at high levels, they are the result of man's activities, particularly waste water disposal. Plant uptake is so small that 85 percent of applied trace element is left in the soil, so maximum application rate should not exceed that which allows normal crop growth.

Boron (B) ranged from $0.30 \mathrm{mgl}^{-1}$ in $\mathrm{RM}$ water to $0.45 \mathrm{mgl}^{-1}$ in the $\mathrm{RB}$ as the lowest and highest levels in these waters as against the Rowe and Abdel-Magid, (1995) standard values of $0.75 \mathrm{mgl}^{-1}$ for long and $2.00 \mathrm{mgl}^{-1}$ for short term irrigation uses. Apart from nutrient benefit, B concentration of more than $2.00 \mathrm{mgl}^{-}$ 1 affect plant metabolism (Mass, 1984). These concentrations are low and may not affect metabolic activities of plants irrigated with the water in the absence of any treatment. These concentrations therefore pose no limitations for irrigated crop production therefore required no management input.

Iron $(\mathrm{Fe})$ concentrations in the $\mathrm{RD}$ and $\mathrm{RM}$ $\left(0.88 / 0.93 \mathrm{mgl}^{-1}\right)$ were higher compared to those of RK and RB (0.44/0.66 $\left.\mathrm{mgl}^{-1}\right)$. The low levels of Fe in these surface waters may likely be due to the trapping of $\mathrm{Fe}$ within suspended organic matter particles (Fe reacts with oxygen to form compounds that do not dissolve in water). The volumes of Rivers Benue and Katsina-Ala were far larger than those of Dura and $\mathrm{Mu}$ rivers. Hence, well aerated (oxygenated) in bigger water bodies will be expected to have far lower levels of $\mathrm{Fe}$ concentrations than the levels in smaller water bodies, (O'conner, 1971). All the parameters in the four major rivers of the study area fall within the permissible limits for irrigation water, in general terms, therefore the quality of water in the Mid-Section of Benue Trough are highly suitable for irrigations, thus, confirming the findings of Agber el tal,. (20017).

Conclusion: The study revealed that all the metals content, the physical as well as the chemical parameters of the river waters examined fall within the acceptable levels for both temporary and permanent irrigation water standards. The rivers of Mid-section of Benue Trough are therefore very suitable as sources of irrigation water.

\section{REFERENCES}

Abagyeh, SOI (2015). Characterization and Irrigation Suitability Ratings of Soils of Mid-Benue Valley Usingg Okra (Abelmoschus esculentus L.Moench) as a Test Crop. Ph. D Thesis Dapartment of Soil Science, University of Agriculture, Makurdi Benue State, Nigeria.

Agber, PI; Nenge, AS and Abagyeh, SOI (2017). Assessment of the Need and Water Potentials for Supplementary Irrigation in the Southern Guinea Savanna Zone of Nigeria. Journal of Biological and Chemical Research. 34 (1) Part A. Society of Advancement in Sciences

Ayers, SR and Westcot, DW (1987). Water Quality for Agriculture. FAO Irrigation and Drainage Paper. No. 29 ref. 1, FAO of UN Rome.

Brady, NC (1999). The Nature and Properties of Soils $12^{\text {th }}$ edition Prentice Hall, Upper Saddle River, New Jersey, USA. Pp 626-755.

FAO (19994). Food and Agricultural Organization of United Nations; Water Quality for Agriculture Irrigation and Drainage Paper 29, Rev. 1. Rome $161 \mathrm{pp}$.

Jamala, GYP; Boni, G; Abraham, A and A, MM (2011). Soil Status and Yield Response of Different Varieties of Okra (Abelmoschus esculentus L. Moench) Grown at Mubi Floodplain, Northeastern Nigeria. Journal of Agric. Biotech. and Sustainable Development. 3(7); 120-125.

James, R (2010). Irrigation Water Greenhouses and Nurseries. University Arkansas, Division of Agriculture, Agricultural and Natural Resources.

Landon, JR (1991). Booker Tropical Soil Manual a Handbook of Soil Survey and Agricultural Land Evaluation in the Tropics and Subtropics. Paperback edition. Longman Science and Technical, U. K. pp 474.

Mass, EV (1984). Soil Tolerance of Plant. In: The Handbook of Plant Science in Agriculture. B R Christic (ed) Boca Raton, Florida CRC Press.

Nagtal, P; Swain (1997). Approved and Working Criteria for Water Quality. CCREM and CCME, 1987 - 97. Canadian Guidelines: Reviewed and Revised Section 5.2 and 5.3.

O'Conner, JT (1971). Iron and Manganese In: Flentie, ME; Faust, RJ ed. Pp. 380-396. Water 
Quality and Treatment, a Handbook of Public Water Supplies. $3^{\text {rd }}$ Ed. Prepared by the American Water Works Association Inc. McGraw. Hill Book Co. NY.

Obi, ME (2000). Soil Physics: A Compendium of Lectures. Department of Soil Science University of Nsukka, Nigeria. Allan Publication.
Offdile, ME (2014). Hydrogeology: Groundwater Study and Development in Nigeria. $3^{\text {rd }}$ Ed. Mecon Geology and Engineering Services Limited. Jos, Nigeria

Rowe, DR and Abdel-Magid, IM (1995). Handbook of Wastewater Reclamation and Reuse. CRC Press Incorporation, 550pp. 